\title{
The true cost of maize silage
}

B.J. FAUSETT ${ }^{1}$, J.S. ROWARTH and F.G. SCRIMGEOUR

${ }^{1}$ Present address: Ravensdown Fertiliser Co-operative Limited, 312 Main South Road, Hornby, Christchurch

Waikato Management School, University of Waikato, Private Bag, Hamilton

Bryce.Fausett@Ravensdown.co.nz

\begin{abstract}
The New Zealand dairy industry has increased significantly in size in over the last two decades. One of the drivers that has made this intensification possible is the use of maize silage as a feed supplement. Growing maize on farm imposes production and opportunity costs on the farm business. Opportunity cost was calculated using data from DairyNZ as the profit foregone due to not milking from the maize-growing hectares. Opportunity cost was added to Pioneer's calculated cost of maize silage production to represent the cost that is incurred for each hectare of maize silage that is planted on farm. The true cost of maize silage grown on farm at differing milksolid (MS) payout levels and farm systems was estimated. The findings indicate the economic appropriateness of growing maize silage on farm depends upon the farm system, the value of MS and the cost to purchase maize silage in a given year.
\end{abstract}

Keywords: Maize, milksolid payout, opportunity cost

\section{Introduction}

The objective of this research was to analyse the economic appropriateness of growing maize on farm relative to other maize silage-sourcing options. Accurate cost information is essential for farmers seeking to optimise farm performance in alignment with their objectives and the constraints they face. Many farmers concentrate on the basic financials that represent the variable costs of maize production and do not consider the opportunity cost of the decision thereby mis-calculating the total financial and economic opportunity cost.

Maize in New Zealand is predominantly grown and harvested as a supplementary feed source for dairy cows. Area has increased in the two decades from 20,000 ha to approximately 78,000 ha, with $90 \%$ in the North Island (Pyke 2014). At the same time, DairyNZ data on farm system (DairyNZ Economic Survey annually) show an increasing use of inputs: more farmers are feeding supplement. This contributes to the intensity of farming (DairyNZ 2015):

System 1 (Low intensity): All grass, self-contained

All grass. No supplement feed purchased. No cows grazing off the milking area.

System 2 (Low intensity): Dry cow feed purchased
Approximately $4-14 \%$ of total feed imported and fed to dry cows including dry cows grazing off the milking area.

System 3 (Medium intensity): Feed purchased for dry cows and to extend lactation Approximately $10-20 \%$ of total feed is imported to the milking area to extend lactation (usually autumn feed) and for dry cows.

System 4 (High intensity): Feed purchased for dry cows and to extend both ends of lactation Approximately $20-30 \%$ of total feed purchased at both ends of lactation and for dry cows.

System 5 (high intensity): Feed purchased for year round feeding At least $30 \%$ of total feed imported all year round including for dry cows.

Since 2000/01, the system 1 farmers have dropped from $41 \%$ to less than $10 \%$ of dairy farms whereas systems 3,4 and 5 have increased from 17,11 and $1 \%$ to $40-45$, 20-25 and 4-9\%, respectively (Greig 2012; DairyNZ 2015).

Maize silage is not the only supplement in the mix; $43 \%$ of supplement has been Palm Kernel Expeller (Ledgard \& Boyes 2013), but large price fluctuations in recent years as well as concerns about sustainability and biosecurity are apparent. Maize silage is popular because of its potential for high yields of 18-26 tonnes of dry matter (DM) a hectare (Densley et al. 2013). Secondly, maize silage has historically been an affordable component of supplementary feed. Pioneer (a self-declared world leading maize seed company), suggests that maize silage can be grown and harvested on farm for 13-25 cents per kg/DM in the stack, subject to yields (Pioneer 2014). A third factor is that maize silage from whatever source can be stored, in either a stack or a bunker until the farmer requires it providing a form of feed insurance. This is increasingly important given the variability in climate over the last few years, including drought in the Waikato four years of the last five.

Over the last ten years the market price for "stacked" maize silage has ranged from a low of 25-26 cents per $\mathrm{kg}$ DM to a high of 42 cents per $\mathrm{kg}$ DM, affected by seasonal demand according to milk price and grass growth. The average price during this time period was approximately 30 cents per $\mathrm{kg}$ DM. A 2008 survey of contractors showed that $36 \%$ of maize silage was 
grown on dairy farms, $24 \%$ on support blocks and $40 \%$ by cropping farmers (Booker 2009).

It is important to recognise that the economics are not the only factors in growing and feeding maize. Aspects such as the nutrient loss mitigation potential, a break crop in pasture renewal and risk mitigation in meeting animal feed requirements during periods when feed demand exceeds supply (e.g., when grass growth is limited by low temperatures or drought) are also important. These aspects have been reviewed elsewhere, e.g., Johnstone et al. 2010; Williams et al. 2007; Densley et al. 2011; Glassey et al. 2014, and are not covered here.

This research was undertaken to calculate the full cost of maize growing in the Waikato region where supplementary feeding has become an important risk mitigation strategy to allow ongoing milk production during drought.

\section{Methodology}

A literature review was undertaken to review the recent history of maize growing in New Zealand. This was complemented by semi-structured interviews with industry professionals. The results of the literature review and the interviews informed financial modelling of the costs of maize production, taking into account opportunity cost from different perspectives.

An opportunity cost is "The cost of an alternative that must be forgone in order to pursue a certain action. Put another way, the benefits you could have received by taking an alternative action" (Investopedia 2014). Determining the opportunity cost of growing maize silage is a key aspect in determining the economic viability of growing maize silage on farm. Consider a farmer who is weighing up whether to grow maize on farm or buy it in from an alternative source. If the farmer was to decide to grow maize on farm, the sacrifice of the alternative use of that land needs to be considered. In order to calculate opportunity cost profit per hectare, estimates were added to Pioneer's calculated cost per hectare for growing and harvesting. In this scenario interest on the land is not taken into the equation as interest will be paid regardless of whether maize silage is grown or purchased.

In the scenario of growing maize on farm rather than purchasing it from a grower, the alternative use or opportunity cost of that land was calculated from the profit that a hectare of dairy land would return. Profit per hectare was calculated from DairyNZ revenue and cost components found in the DairyNZ Economic Survey 2012/13 (DairyNZ 2014).

The price of maize silage when purchased from a grower varies from year to year depending on three key determinants (the milk payout, input costs and the weather conditions) which all affect supply and demand. At the time of analysis, maize silage could be purchased at a price of 32 cents per $\mathrm{kgDM}$. This value was consistent with the forecast and was used as a base line for comparison with alternatives for the coming season; the price for the coming season has yet to be established.

\section{Comparing grown versus purchased maize}

Once a farmer has made the decision to use maize silage as a feed supplement, the next decision is how the maize silage will be sourced: either to grow it onfarm or on a support/runoff block, or to purchase it from a grower.

The decision to grow maize on farm essentially leads to land being taken out of the milking rotation for over half the year. This usually results in a higher stocking rate during this time of year or a decrease in cow numbers.

The decision to grow maize silage on a support block has less of an effect on the practices used on the milking platform. This option allows a farmer to grow maize silage without having a negative impact on stocking rate or cow numbers. When planted in maize, the support block has the opportunity to "grow a maize silage crop that yields 18-26 t DM/ha" (Densley et al. 2013), along with a ryegrass crop of 4-7 t DM/ha. This indicates that the average yield productivity per hectare of the support block is increased, thus further enhancing productivity, resilience and the potential for profit.

If a farmer purchases maize from a grower there are two common options: purchasing with a forward contract or purchasing on the spot market. Purchasing in a forward contract means that the farmer has a set price, set tonnage and an estimated delivery date. This option allows the farmer to have a secure supply of maize silage before the maize is planted, at a fixed price, minimising the risk from market driven price changes. However, locking in at a forward contract price also means that the farmer might pay an inflated price if the maize price decreases as the season advances. Buying on the spot market involves more risk as it means farmers buy the maize silage closer to harvest and as a result are subject to price changes reflecting supply and demand in the market.

Farmers might decide to purchase from the spot market rather than a contract for multiple reasons. Firstly, they might not be sure of their feed demand for the following year and wish to observe grass growth over the summer to help with the decision on whether they require the additional feed supplement. Secondly, they might not have the cash flow to finance the deposits for the maize silage between the contract signing and maize silage delivery (many contracts have one or two deposits required to secure the maize (M. Fausett, pers. comm, September 19, 2014)). 
Farmers can and do exercise a range of choices for varying reasons. For example, a farmer might grow a proportion of their maize silage on farm and then buy in more maize silage from the spot market depending on the yield of their own crop. These decisions can have a significant effect on the way in which the farm is operated and as a result, the profit of the farm.

In addition, many farmers do their budget calculations and feed planning on a particular expected yield output. However, the majority of farmers do not then weigh their crop (grown on farm) as it is harvested. They might receive an estimate on the weight of the crop but estimates are not actual weights: moisture content varies depending on harvest time. For example, a crop that yields 20 tonne at 36 percent DM would yield 22 tonne at 40 percent DM.

The above analysis highlights two key factors. Firstly, the actual costs may differ from budgeted cost, and secondly the estimated quantity of feed from maize used in feed and financial budgets may not be accurate.

\section{Results}

For a maize yield of 20 tonnes/ha, a payout of $\$ 7.50$ (Table 1), \$6.50 (Table 2) and \$6.00 (Table 3), respectively, was required for low, medium and high input systems (Hedley et al. 2006) before growing maize silage on farm became uneconomical at the 2014/15 average price (ca. 32 cents/kg DM) for purchased maize silage. Below these thresholds it was economical to grow the maize for silage on-farm.

With the maize silage purchase price for the 2015/16 season still unknown no definitive conclusions can be drawn, however the following tables can be applied to indicate economic feasibility in the coming season.

\section{Low Input}

With low input systems maize silage is less expensive to grow on farm in cents/ $\mathrm{kg}$ in comparison with medium and high input systems because on a per hectare basis they tend to be producing less milk and hence income. Note that profitability does depend on

Table 1 Maize silage price, cents/kg DM for Low Input Farmers, that can be justified at different milk solid payout

\begin{tabular}{llllll}
\hline Maize Yield (t) & $\mathbf{\$ 4 . 5 0}$ Payout & $\mathbf{\$ 5 . 5 0}$ Payout & $\mathbf{\$ 6 . 5 0}$ Payout & \$7.50 Payout & \$8.50 Payout \\
\hline 16 & 24.07 & 29.44 & 34.80 & 40.16 & 45.52 \\
18 & 21.40 & 26.17 & 30.93 & 35.70 & 40.47 \\
20 & 19.26 & 23.55 & 27.84 & 32.13 & 36.42 \\
22 & 17.51 & 21.41 & 25.31 & 29.21 & 33.11 \\
24 & 16.05 & 19.62 & 23.20 & 26.77 & 30.35 \\
26 & 14.82 & 18.12 & 21.42 & 24.72 & 28.02 \\
\hline
\end{tabular}

Table 2 Maize silage price, cents/kg DM for Medium Input Farmers, that can be justified at different milk solid payouts

\begin{tabular}{llllll}
\hline Maize Yield (t) & $\$ \mathbf{\$ 4 0}$ Payout & $\mathbf{\$ 5 . 5 0}$ Payout & $\mathbf{\$ 6 . 5 0}$ Payout & \$7.50 Payout & \$8.50 Payout \\
\hline 16 & 23.81 & 30.06 & 36.31 & 42.56 & 48.81 \\
18 & 21.16 & 26.72 & 32.27 & 37.83 & 43.38 \\
20 & 19.05 & 24.05 & 29.05 & 34.05 & 39.05 \\
22 & 17.31 & 21.86 & 26.40 & 30.95 & 35.50 \\
24 & 15.87 & 20.04 & 24.20 & 28.37 & 32.54 \\
26 & 14.65 & 18.50 & 22.34 & 26.19 & 30.03 \\
\hline
\end{tabular}

Table 3 Maize silage price, cents/kg DM for High Input Farmers, that can be justified at different milk solid payout

\begin{tabular}{lllll}
\hline Maize Yield $(t)$ & $\$ 4.50$ Payout & \$5.50 Payout & \$6.50 Payout & $\$ 30$ Payout \\
\hline 16 & 23.66 & 31.06 & 38.40 & 45.73 \\
18 & 21.03 & 27.61 & 34.13 & 40.65 \\
20 & 18.93 & 24.85 & 30.72 & 36.58 \\
22 & 17.21 & 22.59 & 27.92 & 33.26 \\
24 & 15.77 & 20.71 & 25.60 & 30.48 \\
26 & 14.56 & 19.12 & 23.63 & 35.59 \\
\hline
\end{tabular}


the ability of the farm manager as in all systems. Of importance, however, is that low input farms tend not to have invested in the infrastructure required for feeding supplement, which can mean wastage is high. Although the analysis in this report suggests that farmers in a low input scenario can grow maize silage cheaper than they can buy it in average payout years, these other factors should be considered. However, in higher payout years the opportunity cost of not having that land in dairy suggests that they would be better to purchase the maize silage from a grower.

\section{Medium Input}

Maize silage in a medium input system was found to be less expensive to grow on farm in comparison with high input systems, but more expensive to grow on farm compared to low input systems. Assuming a maize silage price of ca. 30 cents $/ \mathrm{kg}$ DM, farmers in a medium input scenario can grow maize silage more cheaply than they can buy in years when the payout is less than $\$ 6.50 / \mathrm{kg}$ MS. In years when the payout is $\$ 6.50-\$ 7.50 / \mathrm{kg}$ MS farmers should primarily base their decisions from the non-financial information and in a year with a payout over $\$ 7.50 / \mathrm{kg}$ MS the opportunity cost of not having that land in dairy suggests that they would be better to purchase the maize silage from a grower.

\section{High Input}

Growing maize silage on farm was found to be most expensive in a high input farm system. Assuming a maize silage price of ca. 30 cents $/ \mathrm{kg} D$ D, farmers in a high input scenario can grow maize silage at a similar price to which they can buy in maize silage during a regular payout year (ca. \$6.50) with the additional benefit of minimised risk. However, in higher payout years the severe financial implications of the opportunity cost of not having that land in dairy suggests that they purchase the maize silage from a grower. When risk is considered, overall the high input farmer is best suited to purchase maize silage from a grower and build up a relationship unless it is an extremely low payout year.

\section{Discussion}

It is important that farmers consider these results in conjunction with their specific farm system, as recommendations will alter depending on farm characteristics, the farm system and farm practices.

In all scenarios farmers should take into account the non-financial advantages (e.g., environmental impact, effluent use and pasture renewal) and disadvantages (direct control of crop) along with the financial evidence to enhance their decision making surrounding maize silage in order to make a decision that best suits their farm system.
Expected maize yield is crucially important. Farm location and core biophysical characteristics, crop husbandry and fertiliser applications are all relevant variables.

Milk price is also important and this is volatile in contrast to the more consistent yield potential for the farm. During 2014 the long-term forecast for the milk price was $\$ 6.00 / \mathrm{kg} \mathrm{MS}$, following a price of $\$ 8.40$ / $\mathrm{kg}$ MS in 2013/2014. However, as of May 2015 the forecast for the 2015/2016 season is only in the order of $\$ 5.00 / \mathrm{kg}$ MS.

For low input farmers, the flexibility to be selfsustained and pasture-based shows its relative advantage. With a hard year predicted, these farmers can minimise supplement use and reduce exposure to cost of purchased supplement by growing maize on farm if needed.

For medium input farmers, maize (or some other supplement) might be required in order to maintain cow condition if other adjustments such as early culling to reduce stock numbers are not made. In a low payout year the opportunity cost of the land diminishes and the best maize sourcing option would be to grow on farm and control supplement costs and manage wastage.

High input farmers are probably in a position where they have very little option. Maize silage and other supplements are a necessity for their farm system and unless they have grown maize silage in previous years (implying an adjustment in stock numbers) it is unlikely they can sacrifice land to grow on farm. In most cases the only option is to buy maize silage from a grower.

\section{Conclusions}

The financial and opportunity cost of maize silage grown on farm was found to be significantly higher than the figure indicated by industry participants, because opportunity cost is not included by industry. Results indicate that in the 2013/14 season with an $\$ 8.40 / \mathrm{kg}$ MS payout, the costs to many farmers growing maize would have been more than the price for which it could have been purchased and the opposite is true in the $2014 / 15$ season. With current payout forecasts, the most economical maize silage source is maize silage grown on farm. It is acknowledged, however, that non-financial components and different farm practices impact on farmer decisions with regard to sourcing maize silage.

\section{REFERENCES}

Booker, J. W. 2009. Production, distribution and utilisation of maize in New Zealand. A dissertation for the Degree of Masters of Applied Science. Lincoln University, New Zealand:

DairyNZ. 2014. DairyNZ Economic Survey 2012-13. DairyNZ. 
DairyNZ. 2015. DairyNZ Economic Survey 2013-14. DairyNZ

Densley, R.; Williams, I.D.; Kleinmans, J.J.; McCarter, S.B.; Tsimba, R. 2011. Use of maize silage to improve pasture persistence in dairy farm systems: a review. Pasture persistence symposium. Grassland Research and Practice Series 15: 217-222.

Densley, R.; Williams, I.; Kleinmans, J.; Edmeades, G.; McCarter, B. 2013. Reducing the environmental impact of dairy farming on water and soil quality - a case for maize silage. Genetic Technologies Limited, Auckland.

Glassey, C.; Mashlan, K.; McCarthy, S. 2014. A farm systems perspective on sensible options for reducing nitrogen loss from dairy farms using indicators related to nitrogen surplus and nitrogen conversion efficiency (NCE\%). http://www.massey.ac.nz/ flrc/ workshops/14/Manuscripts/Paper_Glassey_2014. pdf Accessed 12 May 2015.

Greig, B. 2012. Changing New Zealand dairy farm systems. South Island Dairy Event. www.side.org.nz. Accessed 12 May 2015.

Investopedia. 2014. Opportunity Cost Definition. Retrieved from Investopedia. http://www. investopedia.com/terms/o/opportunitycost.asp Accessed 5 March 2105
Johnstone, P.; Parker, M.; Kaufler, G.; Arnold, N.; Pearson, A.; Mathers, D.; Wallace, D. 2010. Growing maize silage in dairy effluent paddocks for two consecutive seasons - effect on crop yield and soil nitrogen. http://www.grassland.org.nz/publications/ nzgrassland_publication_31.pdf

Ledgard, S.; Boyes, M. 2013. Temporal trends in use of supplementary feeds on farms in New Zealand. Client report for Ministry for Primary Industries. 17 pages.

Pioneer. 2014. Growing and harvesting costs calculator. Retrieved from Pioneer: http://www.pioneer.co.nz/ maize-silage/tools/growing-and-harvesting-costscalculator/

Pyke, N. 2014. Maize - a food and feed crop for New Zealand. pp. 115-121 In: New Zealand Agriculture: An Economic Perspective. Eds. Emerson, A.; Rowarth, J.S.; Scrimgeour, F.G. NZX, Wellington.

Williams, I.D.; Ledgard, S.F.; Edmeades, G.O.; Densley, R.J. 2007. Comparative environmental impacts of intensive all-grass and maize silage-supplemented dairy farm systems: a review. Proceedings of the New Zealand Grassland Association 69: 137-143. 
